This PDF is a selection from an out-of-print volume from the National Bureau of Economic Research

Volume Title: Tax Policy and the Economy, Volume 7

Volume Author/Editor: James Poterba, editor

Volume Publisher: MIT Press

Volume ISBN: 0-262-16135-4

Volume URL: http://www.nber.org/books/pote93-1

Conference Date: November 17, 1992

Publication Date: January 1993

Chapter Title: The Unemployment Insurance Payroll Tax and Interindustry and Interfirm Subsidies

Chapter Author: Patricia M. Anderson, Bruce D. Meyer

Chapter URL: http://www.nber.org/chapters/c10879

Chapter pages in book: (p. 111 - 144) 


\section{THE UNEMPLOYMENT INSURANCE PAYROLL TAX AND INTERINDUSTRY AND INTERFIRM SUBSIDIES}

\section{Patricia M. Anderson}

Department of Economics, Dartmouth College

\section{Bruce D. Meyer}

Department of Economics and Center for Urban Affairs and Policy Research, Northwestern University and NBER

\section{EXECUTIVE SUMMARY}

Unemployment insurance (UI) in the U.S. is financed through a payroll tax that is imperfectly experience rated, and thus only partially reflects a firm's use of the system. As a result, certain firms and industries receive many more dollars in unemployment benefits than they pay in taxes. We document that the same patterns of large interindustry subsidies have persisted for over 30 years, and we find that these subsidies are due mostly to differences in layoff rates across industries. Agriculture, mining, manufacturing, and particularly construction receive subsidies, while trade, finance, insurance and real estate, and services consistently pay more in taxes than they receive. Additionally, using previously unexamined firm level data, we document a persistent pattern of interfirm subsidies across several years. Together, these results indicate that UI benefit payments

This paper was prepared for the 1992 NBER conference on Tax Policy and the Economy. We would like to thank James Poterba and seminar participants at Northwestern University for their comments, and Sherryl Bailey, John Steinman, and numerous officials of state employment security agencies for help in obtaining data. Meyer is grateful for support by the NSF through grants SES-8821721 and SES-9024548. 
are predictable, thus weakening arguments for incomplete experience rating that focus on its insurance value to firms faced with large layoff costs. We also find that the efficiency costs of the cross-subsidies to less stable industries may be large, but such calculations depend on differences between marginal and average subsidies that are difficult to estimate.

Unemployment insurance (UI) in the United States is financed through an experience-rated payroll tax. That is to say, the tax rate for a firm partly depends on the benefits paid to its employees. While the bulk of the literature on the incentive effects of UI explores the relationship between UI benefits and unemployment durations, a growing strand of the literature focuses on this system of financing benefits through an experience-rated payroll tax. ${ }^{1}$ This UI payroll tax is quantitatively important, currently raising over $\$ 20$ billion annually. However, certain industries and firms receive many more dollars in unemployment benefits than they pay in taxes, with this subsidization occurring at the expense of other industries and firms. While such a pattern of cross-subsidies is expected in an insurance program at a given point in time, in fact the patterns of subsidies persist, year after year, for the same industries and firms. This continuous cross-subsidization will distort the efficient allocation of resources and increase the aggregate level of unemployment and its accompanying societal costs. Thus, it is important to understand not only the size and patterns of interindustry and interfirm subsidies, but also the degree and source of their persistence. It is also important to know the patterns of UI subsidies, because these likely affect the political economy of support by different industries and firms for UI reform.

Because state UI programs vary in many dimensions, we present evidence for a large number of states. We begin by documenting interindustry subsidies for the last dozen years using aggregate data. We find that the same industries receive subsidies in almost all states and that the subsidies are often very large. The subsidies have only fallen slightly since the changes in the UI finance under the Tax Equity and Fiscal Responsibility Act of 1982 (TEFRA) were implemented in 1985. However, this fall can at least partly be attributed to the reduction in subsidies typically found in better economic times. Even with such reforms, and despite the many changes in the economy in the past decades, there is also a very close correlation between the subsidies received during the last twelve years and those received thirty years ago.

1 Atkinson and Micklewright (1991) is an excellent recent survey of the literature on UI incentive effects, while important early works on UI financing includes Becker (1972), Brechling (1977), Feldstein (1978), and Topel (1983). See Topel (1990) and Hamermesh (1990) for recent work. 
We also analyze the sources of these interindustry subsidies by examining the relative importance of temporary and permanent layoff rates, unemployment durations, and wage and benefit levels. We find that the subsidies are directly attributable to higher temporary layoff rates and, to a lesser extent, to higher permanent layoff rates. Higher industry UI benefits per worker are also partly responsible, but relatively higher tax rates and taxable wages in these industries and lower unemployment durations tend to reduce the subsidy.

While this study and previous studies use industry data to group firms with presumably similar subsidies, industry data are really a proxy for firm data. Firms within the same industry (especially a broadly defined industry) may differ dramatically. In the past, however, firm panel data on UI benefits received and taxes paid have not been available. We use such data and find that the variation in use of UI is as great within industry as it is across industries. While the same firms tend to receive subsidies year after year, these firms are not confined to those industries that receive subsidies overall. Additionally, many firms in subsidized industries consistently pay more in taxes than they receive in benefits.

Thus, at both the firm and industry level, the patterns of redistribution are predictable, such that the unemployment insurance system has a strong element of persistent subsidization. This subsidization reduces labor costs and, thus, the cost of production for unstable industries and firms, and increases it for stable ones. In the case of an interindustry subsidy, it is unlikely to lead to higher industry profits, because entry into the industry would tend to compete away any above-average profits. Rather, the lower costs are likely to be reflected in lower prices, which allows unstable sectors to expand output and employment. ${ }^{2}$ Because our industry groups are broad, part of what we call interfirm subsidies are really industry subsidies at a finer level and are likely to be reflected in product prices. Again, the result is an expansion of unstable firms, which is subsidized by net taxes on more stable ones. However, part of the firm level subsidies likely increases profits without affecting the allocation of resources across sectors.

The degree of persistence of firm level subsidies is important when one is determining how closely experience rated tax payments should reflect UI benefits received. While UI insures workers against job loss, incomplete experience rating of UI also insures firms against having to pay the full UI costs of a large layoff. The rationale for this second type of

2 Deere (1991) examines evidence for such an effect at the broad industry level, concluding that employment in construction is substantially increased, while that in services is decreased. 
insurance to firms is diminished, however, if the frequency of UI claims at a given firm is highly predictable. Thus, our findings of strong persistence in firm use of UI suggest that the firm level insurance costs of tighter experience rating (at least for the large firms we examine) may be smaller than previously thought.

The patterns of UI subsidies also are likely to affect the political economy of support by different industries and firms for changes in UI legislation. Because several billion dollars are currently transferred between industries, and these transfers would be affected by many changes in the UI system, support for reforms is likely affected by these subsidies. The paper proceeds with a brief summary of experience rating systems, before presenting empirical findings on the persistence and causes of interindustry and interfirm subsidies. We then estimate the efficiency costs resulting from the subsidies. The final section then offers some conclusions.

\section{A BRIEF SUMMARY OF EXPERIENCE RATING SYSTEMS}

There are many possible ways to find UI benefits, including using general revenues, employee contributions, employer contributions, or any combination of these. ${ }^{3}$ The United States has chosen to finance its system mainly through a tax on employers, with the tax rate based on some measure of the firm's past experience with the UI system. While overall the tax is only 1.1 percent of total wages and 2.1 percent of taxable wages, the maximum rate (which varies by state) is typically over 6 percent and in several states reaches 10 percent. Currently, employers must pay a 6.2 percent tax on the first $\$ 7,000$ of each employee's wages to the federal government. ${ }^{4}$ However, the law also provides for a credit of 5.4 percent to all employers paying state taxes under an experiencerated UI system. Thus, while each state is free to implement its system as it wishes, there is a strong incentive to implement an experience-rated system, and all states have done so.

These state experience rating systems take many forms, but the two most common are reserve ratio (thirty states) and benefit ratio experience rating (fifteen states). ${ }^{5}$ In a reserve ratio system, a firm's tax rate is a

${ }^{3}$ Atkinson and Micklewright (1991) discuss the systems currently used in some major
OECD countries.

${ }^{4}$ Many states have tax bases higher than $\$ 7,000$ for the state portion of the tax.

5 See National Foundation for Unemployment Compensation \& Workers' Compensation (1990). Michigan and Pennsylvania are counted as benefit ratio states even though they have hybrids of reserve ratio and benefit ratio systems. 
decreasing function of the difference between taxes paid and benefits received divided by average covered payroll. Typically, payroll is averaged over the past three years, while taxes paid and benefits received are summed over all past years and are not discounted. In a benefit ratio system, a firm's tax rate depends on the ratio of average benefits paid to average taxable wages, where both are generally averaged over only the last three years.

Under either system, firm tax rates change in steps as these ratios change. However, for most firms in almost all states, the tax rates do not rise sufficiently when the ratios fall to cause firms to pay the full UI costs of laying off a worker. Additionally, statutory minimum and maximum tax rates imply that there are large ranges at the top and bottom of the tax schedule over which a firm's layoff behavior has no effect on its tax payments. Provisions such as these result in the experience rating being incomplete, so that a firm laying off an employee can expect to pay back less in future taxes than the full cost of the benefits received by that employee. As a result, the system provides an incentive to use temporary layoffs to adjust to demand fluctuations. ${ }^{6}$ Because each state system attempts to balance taxes and benefits over the long run, firms with unstable employment are effectively subsidized by the more stable firms.

In order to clarify the effects of recent changes in experience rating, we describe in general terms how the range of rates and tax base interact to determine the tightness of experience rating. In order for benefit payments to affect a firm's tax payments, the tax rate needs to be able to change in response to a firm's layoffs. Thus, a wider range of rates is generally associated with tighter experience rating. ${ }^{7}$ In addition, a given change in the tax rate will have a greater effect on future tax payments if the taxable wage base is higher.

Until reaching the maximum tax rate, a firm that consistently receives more in benefits than it pays in taxes will face higher future tax payments as it moves up the tax schedule. The more likely it is that a firm is at the maximum rate, the looser is the experience rating. Once at the maximum rate, if a firm receives more benefits, it does not pay additional taxes to compensate and, thus, receives a pure subsidy. The more likely this is to occur, the looser is the experience rating. Thus, one

6 This is in comparison with a perfectly experience rated system. The choice of some experience rating over no experience rating does encourage employment stabilization.

7 However, given a fixed range of rates, there is a tradeoff between the size of the changes in tax rates in response to changes in benefits and the fraction of firms that will be subject to some change. This situation should make it clear that the range in rates is not a complete characterization of the incentives of a tax schedule. 
useful way of summarizing the extent of experience rating is the maximum level of firm unemployment that is consistent with taxes equaling benefits for a maximum rate firm. Here unemployment is measured as the fraction of a firm's workforce that is unemployed on average. Let $\tau_{\max }$ be the maximum tax rate; let $b$ be UI benefits at an annual rate, that is, fifty-two times the weekly benefit; and let $W$ be the taxable wage base. Then the maximum unemployment rate consistent with balancing benefits and taxes is $\mu_{\max }=\frac{W \tau_{\max }}{b}$. Thus, it is an interaction of the tax rates and taxable wage base that helps determine the tightness of experience rating. Consider the case where annual wages always exceed the tax base. Then a proportional increase in all tax rates ${ }^{8}$ and cut in the tax base by the same proportion would leave incentives unchanged. Note that the $\mu_{\max }$ would be unaffected by these changes. The last dozen years have seen roughly these two countervailing changes.

\section{The Effects of TEFRA}

A provision of TEFRA that became effective in 1985 raised the gross federal UI tax rate from 3.4 percent to 6.2 percent and the creditable portion of the federal unemployment tax from 2.7 percent to 5.4 percent. For employers to receive the full credit for federal taxes paid, a state's maximum tax rate had to be at least 5.4 percent. In response, many states followed by raising their maximum UI tax rates. As reported in the first two lines of Table 1, states sharply increased their maximum tax rate and their range of rates between 1982 and 1985. The result was a big jump up in the maximum unemployment rate consistent with balancing taxes and benefits, as seen in the fourth row of the table. By this measure, then, TEFRA succeeded in tightening experience rating. While the higher maximum rates and larger ranges of rates were mostly still in place in 1992, the tighter experience rating created by the changes of TEFRA has been largely eroded by a taxable wage base that has declined in real terms. The federal UI taxable wage base, which was originally the same as the Social Security wage base, has only been raised irregularly since 1935 . While the Social Security tax base is $\$ 55,500$ for 1992 , the UI tax base is only $\$ 7,000$. While states can determine their own tax base for the state part of the UI tax, and sixteen states now index their tax bases, most still follow the federal pattern. UI benefits, however, have generally kept pace with inflation. These trends can be seen clearly in the 17percent decrease in the ratio of the taxable wage base to the average UI

${ }^{8}$ In reserve ratio states, this statement requires a proportional increase in all tax rates for a given difference between past benefits and taxes (the numerator of the reserve ratio), because the denominator of the reserve ratio depends on the taxable wage base. 
TABLE 1.

Summary Measures of State Experience Rating for Selected Years.

\begin{tabular}{lllll}
\hline & 1982 & 1985 & 1990 & 1992 \\
\hline Average of all 50 states & & & & \\
$\quad$ Maximum tax rate & 5.20 & 7.04 & 6.63 & 6.75 \\
$\quad$ Range of rates & 4.26 & 6.05 & 6.16 & 6.16 \\
$\quad$ Ratio of taxable wage base to average benefits & 1.11 & 1.21 & 1.07 & 1.01 \\
Maximum unemployment rate consistent with & 5.62 & 8.46 & 7.09 & 6.75 \\
$\quad$ equal benefits and taxes & & & & \\
& & & & \\
Average of 22 states with industry data & 5.02 & 7.31 & 6.78 & 6.93 \\
Maximum tax rate & 4.08 & 6.28 & 6.33 & 6.38 \\
$\quad$ Range of rates & 1.09 & 1.17 & 1.05 & 0.99 \\
$\quad$ Ratio of taxable wage base to average benefits & & & \\
Maximum unemployment rate consistent with & 5.42 & 8.54 & 7.14 & 6.88 \\
$\quad$ equal benefits and taxes & & & & \\
\hline
\end{tabular}

Sources: Highlights of State Unemployment Compensation Laws, National Foundation for Unemployment Compensation \& Workers' Compensation, various years; and ET Handbook 394 and Supple-

ments, U.S. Department of Labor.
Notes: The numbers are employment weighted averages of the numbers for the individual states. Average benefits are 52 times average weekly benefits. The maximum unemployment rate consistent with equal benefits and taxes is the product of the maximum tax rate and the ratio of the taxable wage base to average benefits. The 1992 average benefit numbers are extrapolated using the 1985-1990 trend. See the text for further explanation.

benefit between 1985 and 1992, reported in the third line of Table 1. Because $\mu_{\max }=\frac{W \tau_{\max }}{b}$, this decline in $\frac{W}{b}$ has resulted in the maximum unemployment rate consistent with a balancing of benefits and taxes falling dramatically since 1985. Thus, most of the strengthening of experience rating under TEFRA has been eroded in recent years because of a federal taxable wage base that has been fixed in nominal terms and, thus, fallen in real terms since 1983, while real benefits have remained approximately constant.

\section{INDUSTRY LEVEL EVIDENCE ON PERSISTENT CROSS-SUBSIDIES}

To establish the extent of interindustry subsidies, we examine a large number of states over as long as twelve years. It is important to examine a large number of states given their diversity of experience rating systems and industrial bases. We also examine as long a period as possible to determine subsidies that are persistent, rather than because of a single transitory downturn. In order to do this, we wrote to each of the fifty states, requesting data on taxes collected and benefits paid since 1980 by industry. About 
half of the states supplied some data, with slightly fewer providing data in a usable form. Thus, the bottom half of Table 1 reports information for twenty-two states that have a variety of experience rating systems and industry distributions, and account for just over 55 percent of total UIcovered employment for the United States. The summary measures indicate that our twenty-two states follow the same time pattern as the other states and have slightly higher taxes and tighter experience rating.

Table 2 gives our main summary statistics for the twenty-two states. For each of eight industries, we report two numbers: the ratio of benefits received to taxes paid and the average annual subsidy to the industry (in millions of dollars) caused by incomplete experience rating. A number greater than one for the benefit/tax ratio indicates the industry received a subsidy, and below it will be a positive number for the average annual subsidy. A number less than one for the benefit/tax ratio indicates that the firm was a subsidizer, so that the subsidy number below is negative. For each state we also indicate the years of data we have available, where the average number of years is 10.8 , and the minimum is eight. The industry benefit/tax ratio we report is the relative benefit/tax ratio defined as $\frac{B_{i} T_{i}}{R}$, where $B_{i}$ is UI benefits received by employees in industry $i$ over the period, and $T_{i}$ is taxes paid by firms in industry $i$, and $R$ is $\Sigma_{i} B_{i} l$ $\Sigma_{i} T_{i}$. We have divided by $R$, the overall state ratio of benefits to taxes, because this ratio often deviates from one over long periods of time. ${ }^{9} \mathrm{We}$ calculate the average annual subsidy to the industry as $B_{i}-T_{i} R$. This subsidy measure accounts for the overall state fund balance by allocating any excess or deficit of taxes over benefits to the industries in proportion to the amount paid in, before calculating the difference between taxes and benefits for each industry. The resulting number, then, represents the interindustry subsidy that would result if the state collected exactly the same amount in taxes as it paid in benefits over the time period, but if at the same time there was no change in the relative tax structure.

In Table 2, there is a striking tendency of the same industries in different states to receive subsidies. In all twenty-two states, construction receives a positive subsidy, and in all but Connecticut, Minnesota, and Vermont, manufacturing also receives one. Agriculture and mining also receive generally positive subsidies. At the other extreme, trade and also finance, insurance, and real estate (FIRE) always receive negative subsidies, that is, they are always subsidizers. In all but New York, transportation and communication subsidizes other indus-

9 There are a number of reasons for long-term differences between benefits and taxes. In some cases we have only charged benefits, which are often much less than total benefits. In addition, state fund balances also go through long-term swings as benefit and tax schedules and unemployment change. 
tries, ${ }^{10}$ while services has a negative subsidy in twenty of twenty-two states. The benefit/tax ratio in construction varies from 1.14 in Tennessee to over 2.0 in Connecticut and Ohio. While agriculture usually receives a modest subsidy, in California the benefit/tax ratio is over 2.0.

In addition to pointing out the predictability of the interindustry subsidies, Table 2 also shows that the magnitudes of these subsidies are no small matter. Even in a very small state such as Maine, $\$ 6.1$ million is transferred annually to manufacturing, and another $\$ 4.1$ million is received by construction, with $\$ 5.1$ million coming from trade, $\$ 2.6$ million from services, and $\$ 2.0$ million from FIRE. In Minnesota, the average annual subsidy to construction is $\$ 43.5$ million, and in the much larger state of Pennsylvania, the subsidy to construction is over $\$ 100$ million, with the loss to trade being almost $\$ 80$ million. The largest subsidy in the table is a $\$ 112.8$ million annual subsidy to agriculture in California.

Table 3 reports several summary measures for our twenty-two states as well as estimated U.S. totals and benefit/tax ratios from thirty years ago. The first line of the table reports the average of the benefit/tax ratios, which vary from 1.66 in construction to 0.56 in FIRE. Note that these numbers imply that construction receives about two-thirds more in benefits than it pays in taxes, while FIRE receives about half of what it pays in. For our twenty-two states together, the total subsidy to construction is over $\$ 650$ million annually, and the subsidy to manufacturing is almost $\$ 290$ million. Trade and services are the largest losers in these cross-subsidies, transferring a combined $\$ 900$ million annually to other industries. If we inflate these numbers by the ratio of total U.S. covered employment to that in our twenty-two states, our results suggest that nationally almost $\$ 1.2$ billion are transferred to construction, while trade and services pay nearly $\$ 1.6$ billion more than they receive. These estimated U.S. totals are reported in the third line of Table 3 and should be treated as rough estimates, because states differ along many dimensions that could make this extrapolation inaccurate.

The fourth line of Table 3 reports the industry benefit/tax ratios for the years beginning with 1985, the first year of the TEFRA provisions. While the cross-subsidies are clearly smaller than they are during the full period, they are only slightly smaller. A decrease would have been expected anyway, because the interindustry subsidies tend to fall in expansionary periods. ${ }^{11}$ It is not surprising that the legislation did not appreciably re-

10 Even the New York numbers would indicate that transportation and communication subsidized other industries were it not for the over $\$ 80$ million in benefits paid because of a 1989 NYNEX strike.

11 See Munts and Asher (1981). 


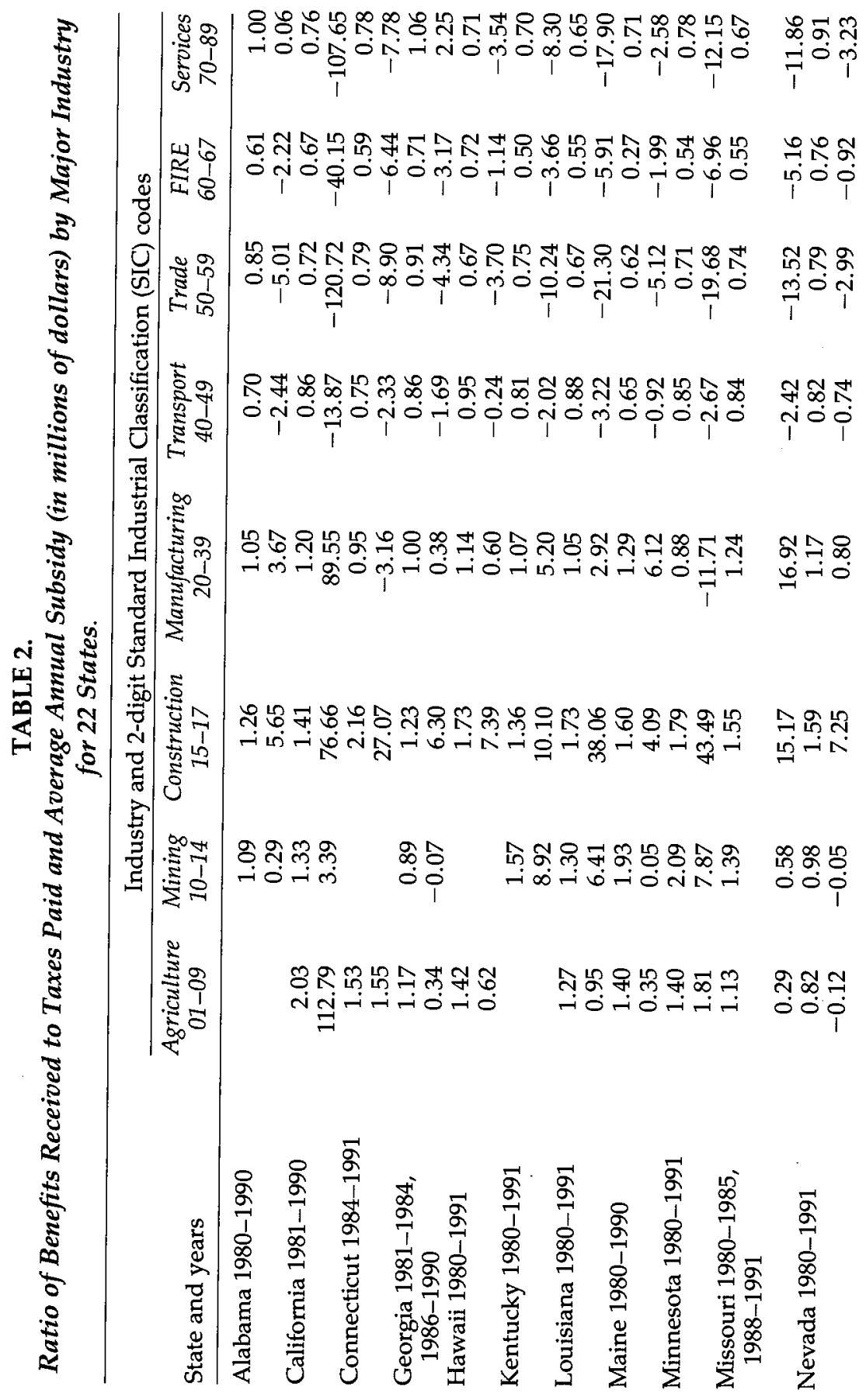




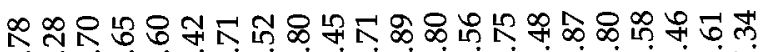

O सं०

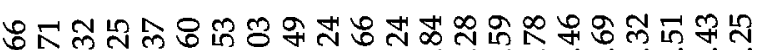
-

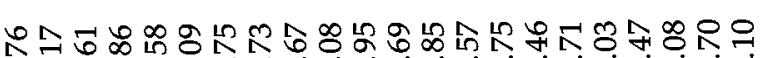
०

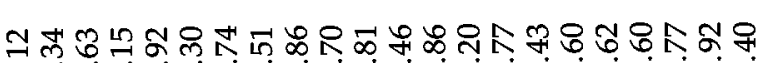

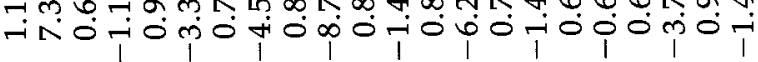

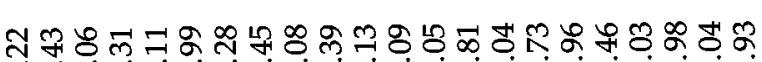

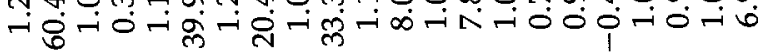

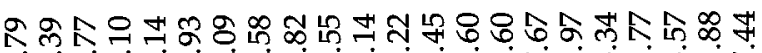

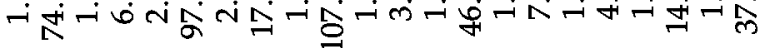

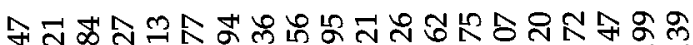

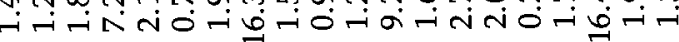

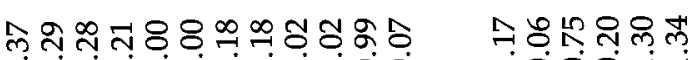

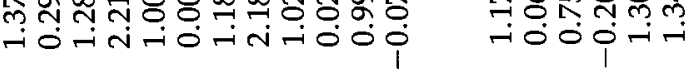

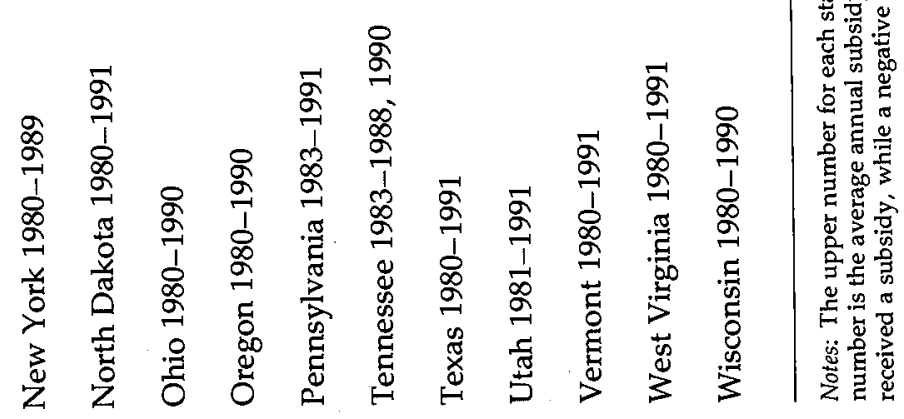




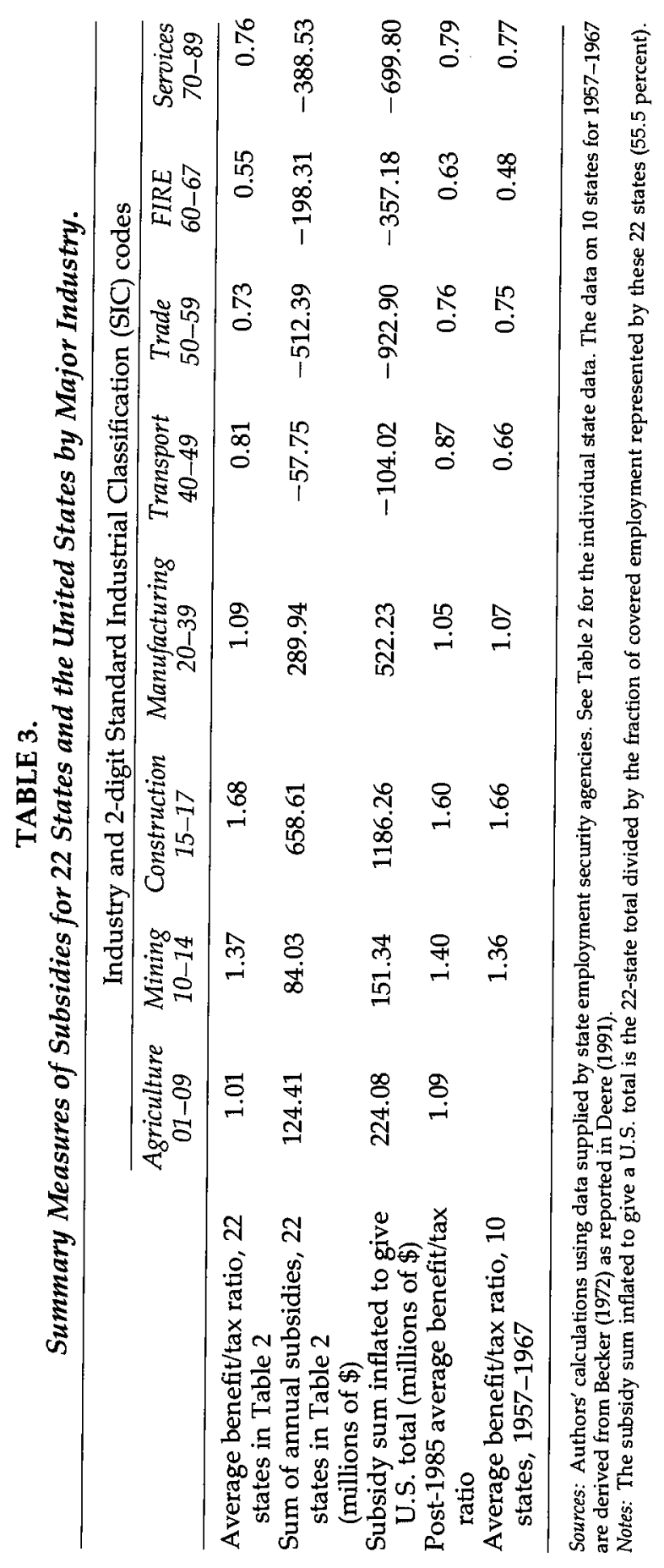


duce the subsidies, because the effects of the changes were quickly eroded away, as discussed earlier.

These results are very much in accord with past research on the subject by Becker (1972), which uses data from the 1950s and 1960s, and by Munts and Asher (1981), which uses data from the 1970s. The statistics presented in the latter are not strictly comparable to those in Tables 2 and 3, but the authors conclude that construction, manufacturing, and agriculture are most likely to receive subsidies, and that trade and FIRE are most likely to be subsidizers. Becker (1972) provides information that is detailed enough to allow us to construct relative benefit/tax ratios by industry in the same manner as Table $2 .{ }^{12}$ We calculate these statistics for the six states that are also available in our new data (California, New York, Ohio, Oregon, Pennsylvania, and Utah) and directly compare the two. While separated by over two decades, the ratios are remarkably similar, with a correlation of 0.83 for the forty-two state-industry observations. We can similarly compare an industry average across all ten states in Becker's data with an industry average for all twenty-two of our states. These numbers for the period 1957-1967 are reported in the last line of Table 3 . The correlation of these averages for the seven industries is 0.99 . Thus, taken together with these past studies, Tables 2 and 3 imply a striking pattern of interindustry subsidies that has persisted for well over thirty years.

\section{CAUSES OF PERSISTENT SUBSIDIES FROM THE UNEMPLOYMENT INSURANCE SYSTEM}

The previous section documented the existence of persistent subsidies resulting from the UI financing system. Given that the interindustry subsidies range in the hundreds of millions of dollars, it is important that we understand their causes. In order to focus on the source of these subsidies, we can decompose the benefit/tax ratio into several key parts. To this consider that this ratio can be expressed as

$$
\frac{B_{i} / T_{i}}{R}=\frac{\left(n_{i} d_{i} b_{i}\right) /\left(t_{i} w_{i}\right)}{(n d b) /(t w)}
$$

Here $n_{i}$ is the total number of UI claims in industry $i, d_{i}$ is the duration of these claims, and $b_{i}$ is the average weekly benefit amount, so that the product of these three terms is total industry benefits. Similarly, $t_{i}$ is the average tax rate and $w_{i}$ is total taxable wages in the industry, which

12 See Becker (1972), pp. 336-337. 
together determine total UI taxes paid. The unsubscripted variables are the equivalent state level variables. Equation (1) can be then rewritten to express the benefit/tax ratio as the product of five ratios:

$$
\frac{B_{i} / T_{i}}{R}=\left(\frac{n_{i}}{n}\right)\left(\frac{d_{i}}{d}\right)\left(\frac{b_{i}}{b}\right)\left(\frac{t}{t_{i}}\right)\left(\frac{w}{w_{i}}\right) .
$$

Decomposing the benefit/tax ratio in this way allows for a simple interpretation of the relative contribution of UI incidence, duration, benefit levels, tax rates, and taxable wages to the overall subsidy. If a given ratio is greater than one, then it is a source of higher subsidies, while if the ratio is less than one, the opposite is true.

While the interpretation of such a decomposition is thus quite straightforward, the data used in Tables 2 and 3, though, like those of the previous studies, do not have the level of detail necessary to perform this decomposition. Data from eight states that were part of the Continuous Wage and Benefit History (CWBH) project, however, do provide this information. ${ }^{13}$ The data consist of UI administrative wage and benefit records for a sample of between 5 and 20 percent of the states' covered workers. We have taken a sample of approximately 150,000 wage records from each state, and matched them with the benefit records by the quarter in which the UI was initiated. Because the wage records contain information on both wages and tax rates, we can compute total UI taxes paid and compare this to benefits received. Additionally, by noting when the firm identifier given on the employee wage record changes, we can identify permanent and temporary separations. ${ }^{14}$

For each industry in each state and for the state overall, we calculate the average incidence, duration, benefits, tax rate, and taxable wages over all the firms. The ratio of industry to state then gives us the sources of the benefit/tax ratio. Each ratio can be thought of as representing the value for an average firm in the industry, standardized by the value for an average firm in the state overall. Additionally, we further subdivide incidence, characterizing claims as arising from either permanent layoffs or from temporary layoffs. ${ }^{15}$

\section{${ }^{13}$ See Anderson and Meyer (1993) for a fuller description of this data set.}

14 In the final data set, the years 1978-1983 are available for Georgia, 1978-1982 for Missouri, 1980-1983 for Washington, 1979-1981 for Idaho, and 1981-1983 for Louisiana, New Mexico, Pennsylvania, and South Carolina.

15 Note that the benefit/tax ratio calculated from the components for this representative firm will not be identical to the ratio for the industry as a whole, but rather is an approximation of that ratio. However, there is a very high correlation of 0.97 between the two measures. 
In Table 4, we summarize the results of the decomposition. The numbers in columns [1] to [5] correspond to the five component ratios given in equation (2). The component ratios were calculated separately for each state, and the table presents the average for that industry across the eight states. Recall that a number less than 1 indicates that the component is responsible for decreasing the benefit/tax ratio, while a number greater than 1 indicates that the component is responsible for increasing the benefit/tax ratio. Thus, while the interpretation of the benefit/tax ratio given in column [6] is analogous to those given in Tables 2 and 3, here it is calculated simply as the product of columns [1] through [5]. ${ }^{16}$ Columns [7] and [8], which decompose incidence into permanent and temporary layoffs, are calculated in a similar manner to column [1]; thus, they are state-industry averages divided by the state average, which are then averaged over all eight states.

First note that as was true in Tables 2 and 3, construction, manufacturing, and mining are being subsidized, and FIRE, trade, services, and transportation and communication are subsidizers. Unlike in those tables, though, in Table 4, agriculture appears as a relative subsidizer. However, there are only a small number of observations for this industry in the CWBH data, making it somewhat less reliable. Several patterns in the sources of the cross-subsidies are evident from Table 4. First, it is clear that the major determinant of an above average subsidy is an above average rate of UI-compensated layoffs. The largest (and smallest) numbers in the table appear in columns [1], [7], and [8]. Especially important to manufacturing, and to a lesser extent to mining and construction, is the above-average incidence of UI-compensated spells that end in recall. This temporary incidence is almost three times that of the average, and close to ten times that for an industry such as retail trade where temporary layoffs are well below average. While the largest variance across industries is found in column [8], that of column [7] is also very large. Thus, while high rates of temporary layoffs are a leading cause of net positive subsidies, above-average rates of permanent layoffs resulting in UI are also to blame, especially in construction. In fact, manufacturing and construction produce this type of UI spell one and a quarter to two times as often as the average.

In manufacturing, the higher overall incidence of UI is accompanied by spells of shorter duration, which work to slightly decrease the sub-

16 Note that column [6] is not the actual average over all eight states, but again represents an approximation based on the experience of an "average" firm from those states. The two measures are very closely related, though, having a correlation of 0.995 . 


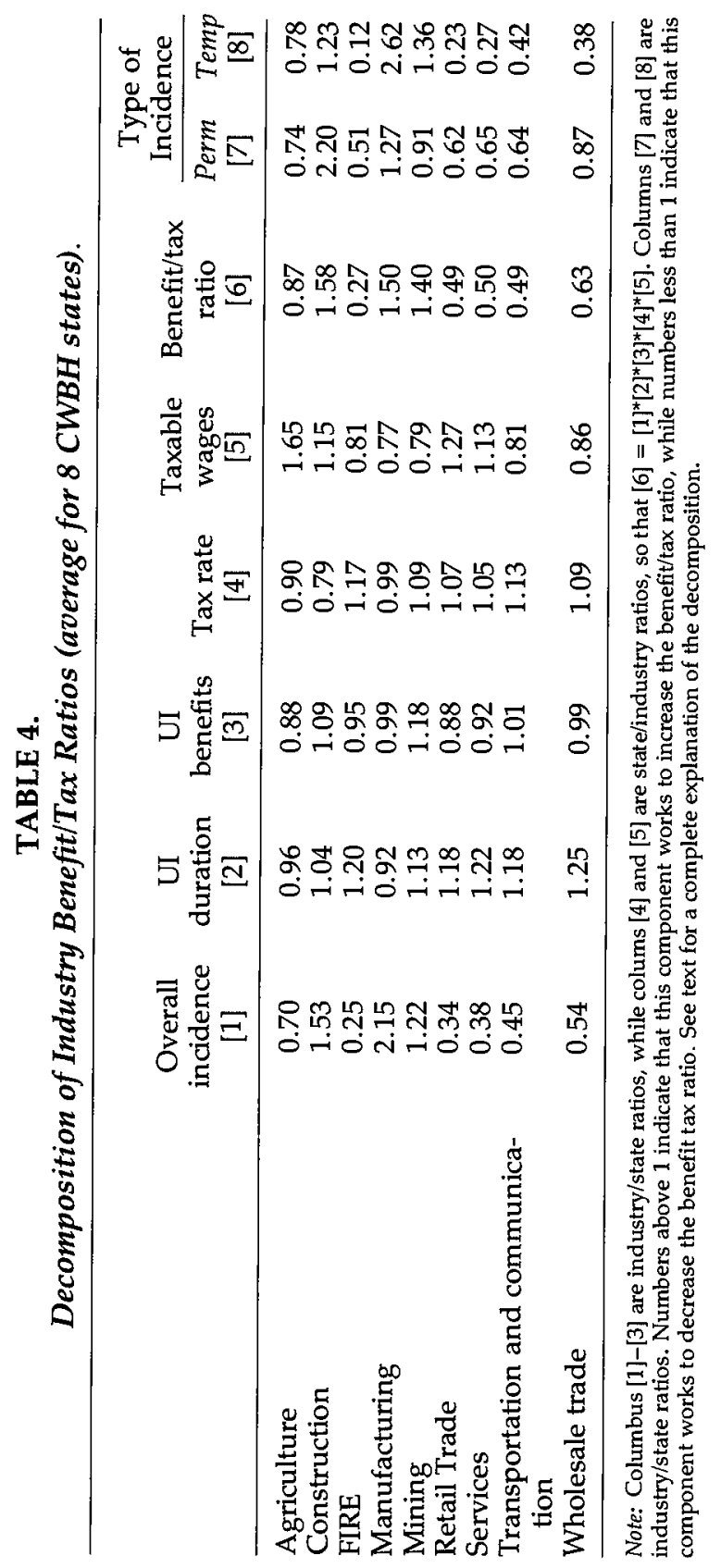


sidy. This is not the case for construction and mining, though, where both duration and incidence contribute positively to the subsidy. The exact opposite is true in agriculture, where both duration and incidence contribute negatively to the subsidy. For all the remaining industries, a lower incidence of UI is somewhat offset by longer durations. In general, though, there is not as much variation across industries in the effects of duration as there is in those of incidence.

In column [5] we see that there is quite a bit of variation in the effect of the taxable wage base. Thus, for example, the high incidence of benefits in manufacturing is somewhat mitigated by a high taxable wage base, thereby decreasing the overall subsidy. This is not the case for construction, however, where the taxable wage base is below average, leading to an increase in the subsidy. Construction is also unique in that this lower taxable wage base does not then result in below average benefit levels, but rather both the taxable wage base and the benefit level (column [3]) contribute to above average benefit/tax ratios. In the other industries, there is a weak tendency for above-average benefits, and taxable wage bases go hand in hand, each partially offsetting the effect of the other on the total benefit/tax ratio.

The main reason taxable wages and benefit levels are not perfectly correlated is that the taxable wage base and the wage base used for determining benefit levels are calculated differently. The weekly benefit level is generally determined as a percentage of high quarter earnings (subject to a maximum), while the taxable wage base is the first $X$ dollars from the employer in a given year, where $X$ is usually around $\$ 6,000$ or $\$ 7,000$. It is easy to see why a highly variable industry such as construction would be particularly helped by this system. For example, in Georgia in 1980, to qualify for UI, a worker needed to earn 1.5 times the high quarter earnings in the base period. The maximum weekly benefit of $\$ 90$ would then be received by anyone with high quarter earnings of $\$ 2,225$ or more. In a stable industry, we would expect base period earnings to be close to four times the high quarter earnings, implying that in qualifying for the maximum weekly benefit, the worker most likely reached the maximum taxable wage base of $\$ 6,000$. For a construction worker, however, the high quarter earnings are likely to be very much higher than earnings in other quarters when work is slack. It would be possible, then, to receive the maximum weekly benefit, while having a taxable wage base that is as low as $\$ 3,338$. While it is likely that base period earnings are in fact more than the minimum of 1.5 times the high quarter earnings, it is clear that they can be considerably below average without a corresponding decrease in weekly benefits. 
Column [4] shows the effect of the tax rate component. The fact that there is not much variation in this effect, given the variation in incidence, points to a key determinant of the persistent subsidization. While the effect of incidence is highly positively correlated with the overall subsidy, the opposite is true for the effect of tax rates. This is due to the design of state experience rating systems, whereby tax rates are higher for firms with more use of the UI system. As Table 4 makes clear, though, the increases in tax rates are not nearly sufficient to offset the effects of increased UI receipt. Thus, the failure of the tax rates to rise along with UI incidence leads to a persistent pattern of subsidization. In insurance terms, the premiums paid by firms do not accurately reflect the risk of loss.

An examination of the state level data on the sources of the crosssubsidies confirms the averages of Table 4 . For the seventy-two stateindustry cells (eight states times nine industries), we calculate covariances of the benefit/tax ratio with the source ratios given in equation (2), as well as the components representing the two types of layoffs. All of the covariances except that with the taxable wage base are significantly different from zero. As expected, the layoff variables have by far the highest covariances with the benefit/tax ratio, 0.43 for temporary layoffs and 0.22 for permanent layoffs ( 0.36 for overall incidence). All other covariances have the expected signs, but are less than 0.04 . In general, then, these results indicate that the averages of Table 4 capture the main relationships in the data.

Overall, the results of the decomposition show that high rates of temporary layoffs for certain industries are the main reason for persistent interindustry subsidies. The relative importance of temporary layoffs compared to permanent layoffs further indicates that cross-subsidies are due not so much to permanent shocks to certain firms in an industry, but rather more to temporary or seasonal changes that lead to short-term employment adjustment. This is an important point, because the insurance value to firms of imperfect experience rating is dependent upon the unpredictability of UI payments. One can also conclude that a key reason for the persistent subsidies is that tax rates do not vary sufficiently to compensate for the differences in layoffs. While imperfect experience rating is a major cause of subsidization, the results also imply that the divergence between the wages on which benefits are based and taxable wages is a significant contributor. Higher benefits and higher taxable wages do not always go hand in hand, because benefit levels are not based on taxable wages, but rather on high quarter wages, and are subject to maxima and minima. 


\section{FIRM LEVEL EVIDENCE ON PERSISTENT SUBSIDIES}

Past work on UI subsidies, such as that by Becker (1972) and Munts and Asher (1981), focused on broad industry groups, because taxes paid and benefits received by laid-off employees were not available at the firm level. ${ }^{17}$ However, the firm is the appropriate unit to analyze because experience rating is done at the firm level. In this section, we once again make use of the newly available CWBH data set that provides just this information, to investigate the persistence of firm-level subsidies. Our data on firm-level subsidies come from the administrative records of two of the states that participated in the $\mathrm{CWBH}$ project. For both Georgia and Washington, we have the UI wage and benefit records for a 10 percent sample of the state's covered workers, and those data cover a period greater than three years. For Georgia the years 1978-1983 are available, while for Washington the time period covered is 1980-1983. In order to be reasonably certain that this 10 percent sample would accurately reflect a firm's UI experience, we limit our data set to records from those firms that had over 1,000 employees at least some time during the period covered by our data. Nonetheless, there is likely to be a good deal of measurement error in our data on firm-level benefit payments.

While Georgia and Washington were chosen mainly because they afforded the longest time spans to examine, they also allow us to contrast two vastly different experience rating systems. In Washington, a truly experience-rated tax schedule only goes into effect if the overall state balances exceed a certain level. Because this was never the case during the time period we examine, all firms were assessed a flat-rate tax of 3 percent. By contrast, in Georgia there are forty-three different tax rates, ranging from 0.07 percent to 5.71 percent in the years 1979-1981, and from 0.06 percent to 5.38 percent in the remaining years. In our data, only 0.3 percent of the firm year observations are at the minimum tax rate, and 2.3 percent are at the maximum. Thus, most of the firms in Georgia face a sloped tax schedule. For all but a few rates, this slope is about 0.44 for the 1979-1981 period, and 0.41 for the other years. These are relatively steep slopes not only in comparison to the zero slope of Washington, but also in comparison to other states with more traditional schedules. Anderson and Meyer (1992) show that in 1981, 93 percent of Georgia employment was at firms who could expect to pay back over $\$ 0.80$ in higher future

17 Marks (1984) approaches the problem at the firm level, but he only looks at persistence in tax rates. 
taxes for each dollar in benefits received. The next closest state was Louisiana, with only 58 percent of employment at such firms. One should note that these measures of the tightness of experience rating partly depend on the types of firms in a state and their behavior. However, our measure of experience rating in section 1, the maximum unemployment rate consistent with paying some cost of additional layoffs, is also considerably above average for Georgia during this period. Thus, a comparison between Georgia and Washington is also a comparison between a state with very tight experience rating and one with effectively no experience rating.

We can use the sample of CWBH data discussed in the previous section to compare these large firms with firms in the state overall. While the general patterns of the industry distribution are fairly similar across the two samples, manufacturing is overrepresented in this large firm sample, as is transportation and communication, with most other industries underrepresented. Construction stands out especially in this regard. ${ }^{18}$ Based on the state sample, the large firms that we use in our sample account for approximately a quarter of total employment in each state. In Georgia, these firms receive 32 percent of the UI benefits, while in Washington, they receive only 21 percent.

For each firm year, we calculate the total amount of UI taxes (state and federal) a firm pays, based on our sample of wage records. We then match any UI benefits received by these workers to the firm employing the worker in the quarter that the benefits were initiated. This allows us to calculate total benefits initiated by the firm's actions for the year and to compare them with total taxes paid. As with the industry group data, in order to account for the effects of the business cycle, we standardize the benefit/tax ratio for each firm by dividing by the overall state benefit/ tax ratio for that year. ${ }^{19}$ Comparing this relative benefit/tax ratio across years then allows us to determine if the same firms are consistently subsidized (or subsidizing) over time. Recall that the argument for UI as firm insurance would imply that large benefit outlays are unpredictable, and, hence, the redistribution implied by insurance principles only would result in no consistent patterns.

Table 5 provides a first indication that, in fact, the redistribution caused by the UI payroll tax may significantly depart from the pure insurance model. Note first that a significant number of firms are either not subsidized at all or are subsidized in almost every year. For example,

${ }_{18}$ About $45 \%$ of the Georgia firm sample is in manufacturing compared with $28 \%$ for the state sample, while for Washington the comparison is $34-20 \%$. For both states, only $2 \%$ are in construction compared with $7 \%$ in the state sample.

19 These yearly ratios were obtained from the sample of $\mathrm{CWBH}$ data discussed in the previous section. 
TABLE 5.

Distribution of Firms, Employment, and UI Benefits by Number of Years Subsidized.

\begin{tabular}{lcrrr}
\hline \multirow{2}{*}{$\begin{array}{l}\text { Number of years } \\
\text { subsidized }\end{array}$} & $\begin{array}{c}\text { Number of } \\
\text { firms }\end{array}$ & & \multicolumn{3}{c}{ Percent } \\
\cline { 5 - 5 } Georgia & & & & \\
0 & 52 & 24.88 & 34.71 & Birms \\
1 & 43 & 20.57 & 19.97 & 6.21 \\
2 & 35 & 16.75 & 13.88 & 8.85 \\
3 & 27 & 12.92 & 11.34 & 12.68 \\
4 & 26 & 12.44 & 11.19 & 22.15 \\
5 & 12 & 5.74 & 4.92 & 21.58 \\
6 & 14 & 6.70 & 3.98 & 14.47 \\
Washington & & & & \\
0 & 113 & 64.94 & 59.63 & 18.90 \\
1 & 19 & 10.92 & 25.72 & 26.32 \\
2 & 7 & 4.02 & 3.16 & 11.57 \\
3 & 13 & 7.47 & 4.69 & 10.55 \\
4 & 22 & 12.64 & 6.81 & 32.67 \\
\hline
\end{tabular}

* Subsidized is defined as (UI benefits/UI taxes) $)_{\text {firm }} /$ (UI benefits/UI taxes) $)_{\text {state }}$ for the year being greater than 1 .

in Georgia 45 percent of the firms are subsidized at most one of the six years, with another 7 percent always subsidized. In Washington, the patterns are much stronger, with 65 percent of the firms never being subsidized and another 13 percent always being subsidized, so that over three-quarters of the firms are at the extremes. Table 5 also presents the percentage of total employment and total UI benefits represented by firms in each category. In both states, over one-third of UI benefits are received by employees at firms that are subsidized in all, or in all but one, of the years. At the same time, though, these firms account for only a small fraction of employment. In fact, in Washington they account for just 12 percent of employment, while receiving 43 percent of benefits. Similarly in Georgia, 9 percent of the employment receives 36 percent of the benefits. Thus, a clear pattern of redistribution is emerging.

Table 6 provides a quick summary of the persistence of subsidies from year to year. The top row of each panel gives the probability that a firm will receive a subsidy in later years, given that it does now. Similarly, the second row of each panel gives the probability that a firm will subsidize other firms in later years, given that it does now. The numbers indicate that there is some tendency for firms to continue over time in their current situation, although this is much more pronounced for firms not 
TABLE 6.

Conditional Probability of a Firm Being Observed in Later Years with Same Subsidy Status as in Current Year.*

\begin{tabular}{lccc}
\hline & \multicolumn{3}{c}{$\begin{array}{c}\text { Probability still receiving/ } \\
\text { not receiving subsidy }\end{array}$} \\
\cline { 2 - 4 } & 1 year later & 3 years later & 5 years later \\
\hline Georgia & & & 0.63 \\
$\quad$ Receiving subsidy in year 1 & $(399)$ & $(216)$ & $(67)$ \\
& 0.79 & 0.70 & 0.73 \\
Not receiving subsidy in year 1 & $(743)$ & $(441)$ & $(142)$ \\
Washington & 0.77 & 0.68 & - \\
Receiving subsidy in year 1 & $(127)$ & $(38)$ & - \\
Not receiving subsidy in year 1 & 0.93 & 0.91 & - \\
& $(417)$ & $(137)$ & \\
\hline
\end{tabular}

Note: Row counts in parentheses

* Subsidy status is determined by (UI benefits/UI taxes) firm $_{\text {/(UI benefits/UI taxes) }}$ state for the year being greater than 1 (receiving subsidy) or less than 1 (not receiving subsidy).

receiving subsidies and for firms in Washington. A useful way to summarize this persistence is to calculate the probability of receiving a subsidy for firms that received one in the past minus the probability of receiving one for those that did not in the past. With no persistence, these differences in probabilities would be zero. For Georgia, this difference in probabilities is $0.42,0.23$, and 0.22 after one, three, and five years, respectively. For Washington, the comparison is more striking, with the difference in probabilities being 0.70 and 0.59 after one and three years, respectively. Thus, knowing a firm's subsidy status today is a very good predictor of its subsidy status in the future.

To help in understanding this persistence more fully, the transition matrices in Tables 7 and 8 provide a more detailed picture of the patterns of redistribution effected by the UI payroll tax in Georgia and Washington. In these tables, firms are classified according to whether their benefit/tax ratio is $0-0.5$ (very small), $0.5-1$ (small), 1-2 (large), or over 2 (very large). Given that a firm is currently in a certain class, the matrices give the probabilities that the firm will be in each of the classes in later years. The probability of remaining in the same class is thus reported by the diagonal elements. ${ }^{20}$ If one turns first to the results for Georgia in

${ }^{20}$ Note that the conditional probabilities presented in Table 6 are equivalent to the diagonals of a transition matrix of this sort where there are only two classes: $0-1$ (no subsidy) and over 1 (receives subsidy). 


\section{TABLE 7.}

1-, 3-, and 5-Year Transition Matrices for Georgia Firms.

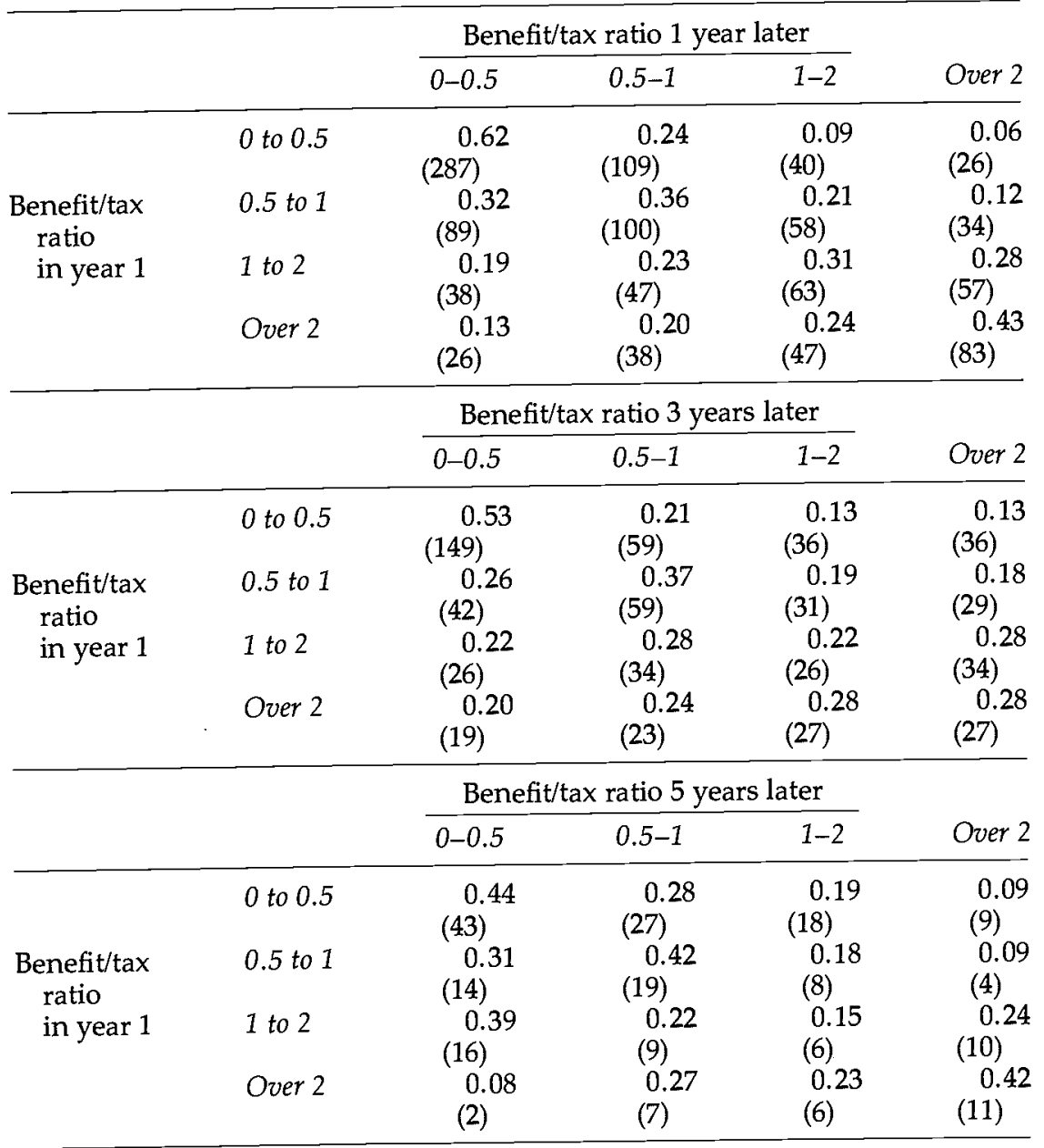

Note: Row probabilities may not add to 1 because of rounding; cell counts in parentheses; benefit/tax

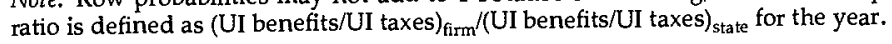

Table 7, there is substantial evidence for persistence of extreme benefit/ tax ratios. The probability that a firm with a benefit/tax ratio over 2 will receive a subsidy five years later is 0.67 , while for a firm that previously had a benefit/tax ratio below 0.5 , the probability of receiving a subsidy five years later is only 0.28 . A stronger degree of persistence of very large benefit/tax ratios is observed in Table 8 for Washington, where the 
TABLE 8.

1- and 3-Year Transition Matrices for Washington Firms.

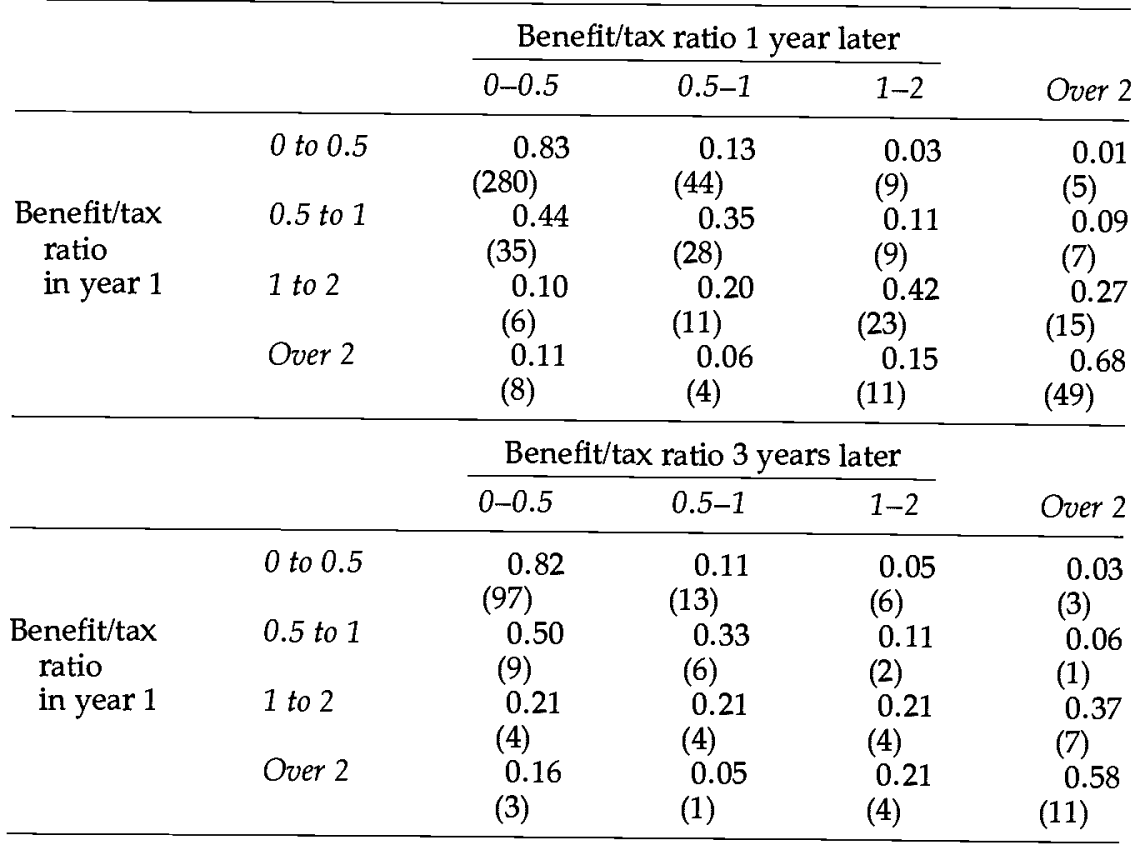

Note: Row probabilities may not add to 1 because of rounding; cell counts in parentheses; benefit/tax ratio is defined as (UI benefits/UI taxes) firm $_{\text {(UI benefits/UI taxes) }}$ state for the year.

probability that a firm with a benefit/tax ratio over 2 will obtain a ratio over 2 again one year later is 0.68 , and it is 0.58 for three years later. Here, the probability that a firm with a benefit/tax ratio over 2 will receive a subsidy three years later is 0.79 , while for a firm that previously had a benefit/tax ratio below 0.5 , this same probability is only 0.08 .

If one looks at those firms with very small benefit/tax ratios in Washington, the persistence is just as striking as it is for those with very large ratios. The probability that a firm with a benefit/tax ratio under 0.5 will obtain a ratio under 0.5 again one year later is 0.83 , while it is 0.82 for three years later. By contrast, for Georgia the probabilities are 0.62 for one year, 0.53 for three years, and 0.44 for five years. As large as some of these probabilities are, it is important to note that the presence of measurement error will cause us to understate the persistence in the benefit/ tax ratios. This is due to the fact that random errors that cause the computed benefit/tax ratio to fluctuate around its true mean will lead to the erroneous appearance of changes in the ratio. 


\section{Firm and Industry Components of the Benefit/Tax Ratio}

Past work on benefit tax/ratios makes comparisons across industries but ignores any variation across firms, within industry. The last findings show that there are persistent interfirm subsidies, but they do not indicate if the subsidies could be predicted based on the industries in which the firms are located, or if other firm characteristics are responsible. It is thus informative to explore what fraction of the variance in benefit/tax ratios is industry-specific, what fraction is firm-specific, and what cannot be attributed to firm or industry. In order to explore this question, we write the benefit/tax ratio for firm $j$ in industry $i$ in year $t$ as

$$
R_{i j t}=\alpha_{t}+\beta_{i}+\gamma_{i j}+\epsilon_{i j t}
$$

where $\alpha_{t}$ captures changes from year to year in the benefit/tax ratio, $\beta_{i}$ captures differences between industries, $\gamma_{i j}$ captures differences between firms within an industry, and $\epsilon_{i j t}$ captures the variation over time for a given firm.

There are several ways to estimate the relative contribution of industry, firm, and other factors to the variance of the benefit $/$ tax ratio. There is no unique decomposition of the variance of $R_{i j t}$. Using the firm-level benefit/tax ratio (adjusted for the state average) as the dependent variable, we estimate equation (3) on the Georgia and Washington data. We use year, industry class, and firm dummy variables for the $\alpha^{\prime} \mathrm{s}, \beta^{\prime} \mathrm{s}$, and $\gamma^{\prime} \mathrm{s}$. The change in the adjusted $R^{2}$ provides a simple summary measure of the fraction of the variance in $R_{i j t}$ explained by the different factors. In Georgia, industry dummy variables add an additional 7 percent to the variance explained by year only, firm dummy variables add an additional 11 percent, and 82 percent of the variance is left unexplained. In Washington, industry dummy variables add an additional 28 percent to the variance explained, while firm dummies add an additional 32 percent, leaving 40 percent unexplained. ${ }^{21}$ When two-digit industry group rather than major industry class is used, the inclusion of firm dummy variables still results in a large increase in adjusted $R^{2}$. In Georgia, twodigit industry explains 11 percent of the variance, with firm explaining an additional 7 percent. For Washington, 38 percent of the variance is explained by two-digit industry, and firm explains another 22 percent. Thus, by this simple measure, across-firm differences are important, even within two-digit industry groups.

21 Year dummies essentially explain none of the variance. This finding is expected, because standardizing by the state ratio should remove the effects of the business cycle. 
A second way of decomposing the variance in $R_{i j t}$ is to directly estimate the variance of the different components of $R_{i j t}$ in equation (3). Again, netting out the time period dummies, the $\alpha_{t}^{\prime}$ s, we can write the variance of $R_{i j t}$ as

$$
\operatorname{Var}\left[R_{i j t} \mid \alpha_{t}\right]=\sigma_{\beta}^{2}+\sigma_{\gamma}^{2}+\sigma_{\epsilon \prime}^{2}
$$

where $\sigma_{\beta}^{2}, \sigma_{\gamma}^{2}$, and $\sigma_{\epsilon}^{2}$ are the variances of $\beta_{i}, \gamma_{i j}$, and $\epsilon_{i j t}$, respectively. There are several standard ways to estimate the $\sigma^{\prime}$ s in the previous equation, with no single preferred methods, so we try two. ${ }^{22}$

There are several conclusions from this exercise that agree quite closely with the results from the comparison of adjusted $R^{2}$ s earlier. The estimated variances, $\sigma_{\beta}^{2}$ and $\sigma_{\gamma}^{2}$, are about equal, indicating that there is about the same amount of variance within industries as there is between industries. As before, this comparison still holds when one looks at twodigit industries rather than industry divisions. ${ }^{23}$ It is also clear that a relatively large fraction of the variance remains unexplained, especially in Georgia. In Washington, though, this residual variance is slightly smaller than the fraction explained by industry and firm. A large part of this unexplained variance, however, is likely due to measurement error, because our benefit/tax ratios are based on a 1/10 sample of employees. We should note that part of the variance that we attribute to firms might be accounted for if we used still narrower industry groups. Nonetheless, the evidence does suggest that the variance across firms (within industry) is as great as that across industry and, hence, that a substantial source of cross-subsidization is ignored in work done at the industry level.

This key finding that there is a considerable amount of persistence in interfirm subsidies, which are not explained by industry alone, has several implications. First, given the magnitude of the interindustry subsidies, this indication that they are only half of the story implies that the cross-subsidy problem is likely to be much greater than past evidence at the broad industry level has suggested. Second, the key argument against more complete experience rating revolves around the idea of insuring the firm against losses from a large benefit payout. As with any

22. We estimate the $\sigma^{\prime}$ s using the method of maximum likelihood, and the MIVQUEO method developed by Hartley, Rao, and LaMotte (1978).

${ }^{23}$ In fact, the fraction of the variance in the benefit/tax ratio attributed to firms rather than industries often rises when one examines 2-digit industries. This surprising result occurs because the estimates of the industry variance are fairly imprecise when one examines industry divisions because one is essentially estimating a variance using only a few observations. 
insurance plan, patterns of interfirm subsidies are expected at a point in time. However, to the extent that these patterns are predictable year after year, the insurance value of the subsidies is lessened. Our findings, then, suggest that the loss in insurance value from tightened experience rating is likely to be smaller than previously thought.

\section{EFFICIENCY LOSSES FROM CROSS-SUBSIDIES}

Much of the past work on UI financing has focused on the distortionary effect of imperfect experience rating on firm layoff decisions. For example, Topel (1983) concludes that 30 percent of layoff unemployment may be due to incomplete experience rating. We would expect imperfect experience rating to also affect the level of employment at firms. Because most firms' tax payments do not equal the UI costs of their layoffs, incomplete experience rating increases the cost of labor of some firms and decreases it for others. Subsidized firms will then increase their size at the expense of firms paying more than their share in taxes. This section estimates the efficiency loss from this distortion of labor costs. We find that these costs are not especially large if the marginal subsidy is not very different from the average subsidy. However, there is little evidence to examine this difference. If the relevant marginal subsidy is much higher, then the welfare costs of the cross-subsidies could be substantial.

The societal losses stemming from the distortion of labor costs across industries can be summarized by measures of deadweight loss (DWL). Topel (1990) provides the only discussion we know of deadweight losses from UI subsidies. Without actual data on benefits and tax payments, however, Topel estimates the subsidy based only on average industry unemployment. He estimates that the DWL caused by the subsidy to construction alone is $\$ 300$ million annually and that accounting for the difference between marginal and average subsidies (a point discussed later) could make the losses much larger. However, while we are interested in comparing the current UI system to a perfectly experience-rated system, Topel compares the current system to the situation of no unemployment insurance. As a result, his measure of the UI employment subsidy includes the effect of the nontaxation of UI benefits that was in force prior to $1987 .{ }^{24}$ If one uses Topel's method for calculating the DWL, but accounts for the taxation of benefits, the resulting DWL is $\$ 86$ million rather than $\$ 300$ million. This difference should be kept in mind when one compares our results to those in. Topel (1990).

24 His estimates also implicitly assume that UI benefits are valued dollar for dollar by workers and the firm. 
We begin by providing estimates of the efficiency loss assuming that all firms in a given industry in all states have the same subsidy rate, and that the marginal subsidy is the same as the average. If one defines $S$ as the dollar subsidy to an industry over its total payroll, the deadweight loss as a fraction of payroll for a given industry can be approximated as DWL $=0.5 \epsilon S^{2}$ where $\epsilon$ is the elasticity of labor demand for firms in that industry. ${ }^{25}$ In Table 9, we present the average industry subsidies from Table 3 , both as a dollar value per employee and as a fraction of the total industry payroll. We then estimate a dollar value for the deadweight loss triangle, based on 1985 average industry payroll and a value of 1 for the elasticity of labor demand. ${ }^{26}$ In general the absolute value of the subsidies is relatively small when compared to industry employment and payroll. Only in construction does the subsidy amount to even a full percentage point of payroll, and for most other industries it is less than half of 1 percent. Similarly, annual subsidies per employee are under $\$ 100$ for all but mining and construction. The overall deadweight loss estimate of Table 9 is $\$ 10.24$ million with $\$ 6.22$ million of the total loss coming from construction alone. ${ }^{27}$ However, as discussed further later, there are several reasons why these estimates are likely to understate severely the true efficiency losses.

One obvious problem with these estimates is that they reflect only the loss from the labor misallocation across industries, while, as we have shown earlier, the across-firm variation within industry is equally if not more important. A simple example will serve to illustrate how important this difference is. Imagine an industry made up of equal numbers of two types of firms: one type always receives a 5 percent subsidy, and the other always provides a 5 percent subsidy. While there will be no subsidy calculated at the industry level (and, hence, no misallocation), there is actually a deadweight loss equal to 0.125 percent of payroll at each and

25 To see this, consider that the welfare triangle over total payroll can be defined as $\mathrm{DWL}=$ $(0.5 \Delta W \Delta N) / W N$, where $W$ is the average wage, $N$ is employment for a given industry, and $\Delta$ means the change in the variable following. Noting that $\epsilon=(\Delta N / N) /(\Delta W / W)$ and $S=\Delta W /$ $W$ leads to the expression given.

${ }^{26}$ Industry payroll figures are from the Monthly Labor Review. Hamermesh (1986) reviews estimates of labor demand elasticities, finding that industry-level constant-output elasticities range from 0.3 to 1.0 , while allowing output to vary leads to estimates between 0.4 and 2.6. Because firm demand should be closer to the latter, we use 1.0 as an estimate of the elasticity. Additionally, because the DWL is proportional to $\epsilon$, one can easily multiply the given DWL by an alternate elasticity if desired.

27 Given our $\$ 6$ million number, one might wonder how Topel arrived at his $\$ 300$ million figure. We indicated that his figure would be $\$ 83$ million now that benefits are taxable. He also appears to have assumed values for the construction industry unemployment rate and the maximum tax rate that are extreme and increase the subsidy. In addition, he appears to have left out the 0.5 in the DWL formula earlier. 
TABLE 9.

Estimated Deadweight Loss from Labor Misallocation.

\begin{tabular}{|c|c|c|c|c|c|}
\hline & $\begin{array}{l}\text { Employment } \\
\left(1000^{\prime} s\right)\end{array}$ & $\begin{array}{l}\text { Weekly } \\
\text { earnings } \\
\text { (dollars) }\end{array}$ & $\begin{array}{l}\text { Subsidy as } \\
\text { a percen- } \\
\text { tage of the } \\
\text { annual } \\
\text { wage bill }\end{array}$ & $\begin{array}{l}\text { Dollar } \\
\text { value of } \\
\text { subsidy } \\
\text { per } \\
\text { employee }\end{array}$ & $\begin{array}{c}\text { Dollar } \\
\text { value } \\
\text { of dead- } \\
\text { weight loss }\end{array}$ \\
\hline Mining & 930 & 520 & 0.60 & 162.73 & 455,468 \\
\hline Construction & 4,687 & 464 & 1.05 & 253.10 & $6,220,557$ \\
\hline Manufacturing & 19,314 & 386 & 0.13 & 27.04 & 351,773 \\
\hline Transportation & 5,242 & 450 & -0.08 & -19.84 & 44,080 \\
\hline Trade & 23,100 & 219 & -0.35 & -39.95 & $1,621,519$ \\
\hline FIRE & 5,953 & 289 & -0.40 & -60.00 & 713,000 \\
\hline Services & 21,974 & 256 & -0.24 & -31.85 & 835,685 \\
\hline Total & & & & & $10,242,082$ \\
\hline
\end{tabular}

Note: Employment and Earnings numbers are annual averages for 1985 and are from Monthly Labor Review (1986).

every firm (assuming $\epsilon=1$ ). We can use our firm-level data to estimate how this across-firm misallocation compares to that across industries. Looking at our firms in Georgia, and summing taxes, benefits, and payroll across all firms within an industry, we obtain average subsidies that are very close to those in Table $9 .{ }^{28}$ However, using the firm-level information to calculate the deadweight loss at each firm, and then summing across all firms in each industry, results in a dollar value for the deadweight loss that is 4.56 times larger than the one calculated based on industry averages. ${ }^{29}$ Thus, because firms within industries vary substantially as to their subsidy status, looking only at the across industry misallocation severely understates the extent of the efficiency losses.

A very similar source of understatement is our use of the average U.S. subsidy rather than state-level subsidies. Just as relying on total industry subsidies rather than firm-level subsidies loses a source of variation, so too does using a national average. Annual payroll is available at the state level for manufacturing establishments, though, allowing us to gauge the importance of this type of aggregation. When we calculate a separate deadweight loss value for each of the twenty-two states and then sum them together, we estimate a loss that is 1.66 times that obtained using

${ }^{28}$ We use Georgia rather than Washington because its experience rating system is more representative of the United States.

29 The six-year average of taxes, benefits, and payroll are used for each firm. This measure is likely to somewhat overstate the firm-level DWL, since some of the firm variability will be due to the sampling error inherent in looking at only a six-year period. 
the average subsidy over these states. ${ }^{30}$ Again, we appear to understate the deadweight loss in Table 9.

A third problem is more difficult to summarize but no less important. All of the previous discussions are based on the assumption that the average subsidy that we are able to calculate is identical to the marginal subsidy that is appropriate for firm decisions. However, the marginal subsidy may well be much greater than the average subsidy. Because the deadweight loss increases with the square of the subsidy, this difference could be very significant. For example, consider the case of a seasonal firm that lays off a fraction $x$ of its workers for one-half of the year. ${ }^{31}$ For the case of a 40 percent replacement rate (about the average), total UI benefits are 40 percent ${ }^{\Delta}$ of the labor costs of the marginal seasonal employee's wage bill (this is calculated as $(0.4)(1 / 2) /(1 / 2)$ ). Because the UI tax is rarely more than 2 percent of average wages, nearly all of this 40 percent would be a marginal subsidy to seasonal employment. For now, then, we will ignore UI taxes completely. By contrast, the average subsidy at this firm is $(x(0.4)(1 / 2)) /(x(1 / 2)+(1-x)) .^{32}$ If seasonal workers are one-tenth of employment $(x=.1)$, for example, then the marginal subsidy is 40 percent, while the average subsidy is 2.1 percent. Again, because the DWL is proportional to the square of the subsidy, the difference between average and marginal can have a large impact on the efficiency losses.

Unfortunately, it is difficult to gauge overall how much the marginal subsidy is likely to differ from the average. We might expect the divergence to be especially large in seasoning industries such as retail trade, construction, and some types of services and manufacturing. This understatement will be more of a problem the smaller $x$ is, because in general if only a fraction $x$ of the workforce is seasonal, the marginal subsidy will be more than $1 / x$ times greater than the average measured subsidy. ${ }^{33}$ It is important to note, though, that the marginal subsidy should probably only apply to the fraction of the workforce that is seasonal. Overall, though, this relationship is one more reason to believe that the small

\footnotetext{
${ }^{30}$ For our sample, the $\$ 290$ million subsidy to manufacturing represents about 0.13 percent of total payroll in those twenty-two states, and implies a deadweight loss of about $\$ 194,000$. Note that the larger dollar value given in Table 9 reflects having inflated the numbers for our twenty-two states to represent the United States as a whole. Using the individual state subsidies results in a total deadweight loss of almost $\$ 322,000$.

${ }^{31}$ This example is a slightly modified version of one in Topel (1990). With a 40 percent replacement rate, most states' potential duration rules would allow a person to receive UI for just under one-half of the year. Thus, this example is close to the extreme case.

${ }^{32}$ Note that if $x=1$, this simplifies to the expression given earlier.

33 See the previous formula. For small $x$, the ratio is approximately $2 / x$.
} 
deadweight loss estimates of Table 9 are gross underestimates of the true loss, especially in some key industries.

To assess the overall effect of the previous three adjustments to the national industry level deadweight loss estimates of Table 9 , we must combine the effects of the difference between firm and industry, state and nation, and marginal and average subsidies. The Georgia estimates of the difference between firm and industry subsidies suggested that the firm DWL estimates are 4.56 times higher. Similarly, the manufacturing industry data imply state subsidies 1.66 times higher than those using the U.S. average. Combining these factors with the subsidy estimates of Table 9 yields a total U.S. deadweight loss estimate of $\$ 77.51$ million annually. While this is a substantial loss, it is fairly small relative to the $\$ 20$ billion annual cost of UI. We have very little basis to assess the additional effect on the deadweight loss estimates of the difference between marginal and average subsidies. We can, however, say that if the marginal subsidies are $z$ times higher than the average subsidies (but apply to $1 / z$ of the workforce), the implied annual DWL is $\$ z(77.51)$ million. Because $z$ could be fairly large, the true deadweight loss caused by incomplete experience rating could be substantial. ${ }^{34}$

Besides this deadweight loss from the misallocation of resources, there are also losses from increased unemployment. This loss occurs because the firms whose expansion is most subsidized are those for whom unemployment is the highest, and marginal subsidies are the greatest for employees who are regularly unemployed. If one notes that the percentage change in employment implied by a subsidy is simply $S \epsilon$, it is straightforward to calculate the change in employment implied by a subsidy. For example, based on the information in Table 9, employment in construction is 1.05 percent, or 49,000 , greater than it would be in the absence of a UI subsidy. If these 49,000 workers have the same average unemployment rate as the industry overall, construction industry unemployment would rise by 6,400 . However, it is reasonable to assume that the additional workers hired because of the subsidy will experience more unemployment than the average worker. In the most extreme case, the additional workers are unemployed half the year. In this case the increase in unemployment in construction would be about 24,500

${ }_{34}$ To be consistent with the average subsidies we observe, a marginal subsidy higher than the average must apply to only some fraction of employment. This assumes that all firms in a subsidized industry receive subsidies and that the same labor demand elasticity applies to all sectors of all firms' employment. For example, if the marginal subsidy in an industry is five times the average, then it could only apply to $1 / 5$ of the industry workforce. Thus, the DWL in that industry would rise by a factor of 5 because the DWL per employee would rise by the factor of $5^{2}$ but only apply to $1 / 5$ of the industry employment. 
workers. Some of this increase would be offset by a decline in unemployment in industries with decreases in employment, but this calculation suggests there are moderate increases in unemployment caused by the cross-subsidies.

Overall, it is clear that there are efficiency losses in the current UI tax system, which stem from the fact that there is a tax on employment at relatively stable firms and a subsidy for relatively unstable firms. This misallocation implies that aggregate output could be increased by redirecting resources. Additionally, the subsidies lead to increased unemployment rates, given the larger workforces at the less stable firms. Although it remains difficult to measure the exact size of these losses even with our new data, it is clear that looking only at national industry level cross-subsidization will lead to a severe underestimation of the loss.

\section{CONCLUSIONS}

In this paper, we present several key findings on the nature of the interindustry and interfirm subsidies generated through the UI payroll tax. We document that the same patterns of large interindustry subsidies have persisted for over thirty years, and we find that these subsidies are due mostly to differences in layoff rates across industries. It is especially temporary layoff rates, combined with tax rates, that do not reflect these differences in layoffs that are responsible. This importance of temporary layoffs (relative to permanent changes in employment) indicates to a large extent that the benefit payments are predictable. Thus, it is a finding that weakens arguments for incomplete experience rating as insurance for firms against large layoff costs. While high temporary layoff rates that are not matched by higher tax rates are the main contributor to large interindustry subsidies, we also find that the divergence between the levels of wages on which taxes and benefits are calculated contributes to the subsidies, albeit to a lesser extent.

Our exploration of interfirm subsidies provides more evidence on the predictability of benefit payments. Using previously unexamined firm level data, we document a persistent pattern of benefit/tax ratios over several years. We find that a firm currently receiving a subsidy from the UI system is much more likely to be still receiving a subsidy three to five years later than a firm that is not currently subsidized. This result implies that to a significant degree, the interfirm subsidies are regular transfers, rather than insurance for firms, thus further weakening the argument for incomplete experience rating. An additional finding of our work with firm level data is that much of the variation across firms in UI benefit receipt and tax payments is not captured by industry data. Thus, 
past work performed at the industry level is likely to have revealed only a fraction of the cross-subsidies carried out by the UI payroll tax.

The interindustry and interfirm subsidies that we document will have real effects on the economy. First, subsidized firms and industries will be larger, while those doing the subsidizing will be smaller. This misallocation of resources leads to a deadweight efficiency loss. While even with our new data sources it is difficult to attach an exact dollar value to this loss, we argue that it may be substantial. Additionally, there is an effect on aggregate unemployment, because it is just those workers who are most likely to be regularly unemployed who are most subsidized. Again, the data is not available to arrive at precise estimates of the effect, but we find that UI cross-subsidization may be responsible for substantial unemployment in such industries as construction.

\section{REFERENCES}

Anderson, Patricia M., and Bruce D Meyer (1992). "The Incentives and CrossSubsidies of the UI Payroll Tax" (with Patricia Anderson). Working paper, March 1992.

and (1993). "Unemployment Insurance in the United States: Layoff Incentives and Cross-Subsidies." Journal of Labor Economics 11.

Atkinson, Anthony B., and John Micklewright (1991). "Unemployment Compensation and Labor Market Transitions: A Critical Review." Journal of Economic Literature 24, 1679-1727.

Becker, Joseph M. (1972). Experience Rating in Unemployment Insurance: An Experiment in Competitive Socialism. Baltimore: The Johns Hopkins University Press.

Brechling, Frank (1977). "The Incentive Effects of the U.S. Unemployment Insurance Tax." In Research in Labor Economics, vol. 1. Ronald Ehrenberg, ed. Greenwich, CT: JAI Press.

Deere, Donald R. (1991). "Unemployment Insurance and Employment." Journal of Labor Economics 9, 307-324.

Feldstein, Martin S. (1978). "The Effect of Unemployment Insurance on Temporary Layoff Unemployment." American Economic Review 68, 834-846.

Hamermesh, Daniel S. (1986). "The Demand for Labor in the Long Run." In Handbook of Labor Economics, Orley C. Ashenfelter and Richard Layard, eds. Amsterdam: North-Holland.

- (1990). "Unemployment Insurance Financing, Short-Time Compensation, and Labor Demand." Research in Labor Economics 11, 241-270.

Hartley, H. O., J. N. K. Rao, and L. LaMotte (1978). "A Simple Synthesis-Based Method of Variance Component Estimation." Biometrics 34, 233-244.

Marks, Denton (1984). "Incomplete Experience Rating in State Unemployment Insurance." Monthly Labor Review 107, 45-49.

Munts, Raymond C., and Ephraim Asher (1981). "Cross-Subsidies Among Industries From 1969 to 1978." Unemployment Compensation: Studies and Research, 277-297.

National Foundation for Unemployment Compensation \& Workers' Compensa- 
tion (various years). Highlights of State Unemployment Compensation Laws. Washington, DC: NFUCWC.

Topel, Robert H. (1983). "On Layoffs and Unemployment Insurance." American Economic Review 73, 541-559.

(1990). "Financing Unemployment Insurance: History, Incentives, and Reform." In Unemployment Insurance. W. Lee Hansen and James F. Byers, eds. Madison, WI: University of Wisconsin Press. 